\title{
DETERMINANT ANALYSIS OF HUMAN DEVELOPMENT INDEX IN OF NORTH SUMATERA PROVINCE
}

\author{
Ribka Sari Butar Butar $\left.{ }^{1 *}\right)$, Rahmanta ${ }^{2}$ \\ ${ }^{1 *}$ Departmen of Economics, Postgraduate Program Universitas Negeri Medan \\ ${ }^{2}$ Facultu of Agriculture, Universitas Sumatera Utara \\ Email: ribkas.89@gmail.com
}

\begin{abstract}
The results showed that the number of poor people and government expenditures from the aspect of health funds had a significant effect on the HDI. While open unemployment and government spending from the aspect of education fund did not significantly affect the Human Development Index. The success of the economic development of a region can be seen from the high economic growth, with the increase of economic growth is expected also can improve the welfare of society and increase human development with indicator of Human Development Index (HDI).
\end{abstract}

Key words: Human Development Index (HDI), Poverty, Unemployment, Government Expenditure Health Aspects and Education Aspects, Multiple Linear Regression Panel Data

\section{INTRODUCTION}

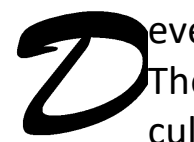

evelopment means an increase or progress to attempt improvement for better. The development includes variable aspects of social, politic, economy, and

culture developments. Therefore, Development is the fundamental provision of sustainable country. The core component or value defines as economic development success is categorized for having substances, self-esteem, and freedoms, as of those are the goal achievement of every individual in socialism (Tadoro, 2006:26). Within the continuing striving of development, expected to have good effect for individuals in North Sumatera, especially toward the growth of economic welfare. Yet prosperity seems impossible when the authority is incapable to run the efficiency of limited sources. The inability can lead to the possible worst outcome toward the health and economic collapse which eventually reach the peak of misery. Poverty has always been the main concerned of socialist and authority in a district, state and international scale so that various efforts are applied to reduce the poverty rate. According to Millennium Development Goals (MDGs), stated that the rate of poverty of a country should show increase reduction half prior to the previous year in 2015 (Tadoro and Smith, 2006:29). Poverty categorized as multidimensional problems in preventing developmental success because it is involved in other aspects including social, economy, culture and others. Poverty is also defined as a situation or condition experiencing by any person or group who are unable to have standard of living of so called humanity. The settlement of poverty relief is hoped not only contribute from the growing economy sector, but also 
rely on other economic sides such as human development (educational improvement, health-care system, and per-capita expenditure) and create more jobs to lower number of unemployment that will rescue our society from poverty and arouse amount of prosperity in community. Unemployment is caused by an increase number of work force that increase every year, simultaneously available space of labor does not increase. In addition, the accident of bankrupt industries had to forcefully lay off workers. This means that the high number of unemployed will firmly raise number of poor people. The quality of human resources can also be a factor in the occurrence of poor people. The quality of resources can be seen from the quality of life index / human development index. The low Human Development Index (HDI) will result in low work productivity of the population. Low productivity results in low income generation. So that low income causes the number of poor people. Improving human quality is the main target of economic development, this means that all resources needed in development must be managed to increase human skill (UI Haq, 1998).

Unemployment affects the Human Development Index (HDI). Unemployment costs weak economic prosperity in community, therefore the ultimate goal accordingly is to build focus of community prosperity and welfare. When the unemployment rate in an area is high, it will hamper the achievement of economic development success. Community income decrease inflicting people's low purchasing power in market, leading to education and health which are basic needs to improve human quality cannot be fulfilled (Baeti, 2013: 90). Poverty and unemployment have quite serious effects on human development because they are complex problem. Which stems from the purchasing power of the people who are unable to meet basic needs so that other needs such as education and health are neglected. The following are developments in the number of poor people and the open unemployment rate in North Sumatera Province.

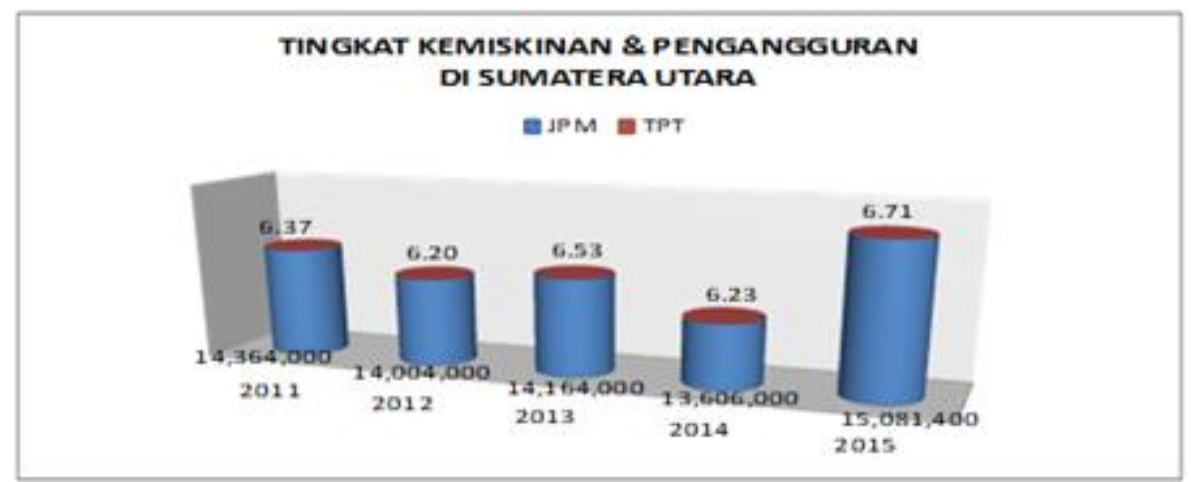

Figure 1: The Measurement of Poverty and Unemployment rate in North Sumatera Province, 2011-2015

Source: BPS Indonesia (Proceed)

The unemployment issue considered the toughest to overcome is the open unemployment, which is the labor that has no job and is looking for or preparing for work. The 2012 open unemployment rate in North Sumatera was 6.20 percent. This figure is indeed smaller the previous years of 2011 and 2010, which were respectively 6.37 percent and 7.43 percent, but was still above the national unemployment rate 
average for the same two years, 2012 and 2013, namely 5.92 percent. The trend in open unemployment rate is certainly a positive signal for welfare in North Sumatera. The inflation of poor communities is sufficiently encouraged by the conduciveness of the economy because poverty is direct link toward income, while the income is gained throughout economic activities. The poverty condition in North Sumatera from 2011 to 2015 was still lower comparing to the decline in the national level. The government as the implementer of development certainly needs quality human capital as the basic capital of development. To produce the quality of human beings, hardworking are needed to improve the quality of human resources. The government makes expenditures or investments aiming to strike human development.

Government expenditure is taken based on reflection analysis of policy by the government. In this case, government expenditure is used to finance the public sector as the main importance and a priority to grow human quality resources as reflected in the Human Development Index (HDI). The government's role in increasing the Human Development Index is also influential through the realization of state expenditure in public services. The role of the government in the policy of implementing regional autonomy and fiscal decentralization is based on the consideration that the regions know better about the needs and standards of service for the people in their regions. So that the provision of regional autonomy is expected to spur an increase in the welfare of the people in the regions by increasing economic growth. Government expenditure is used to finance important public sectors, among all the current public sectors which are the priority of the government in achieving development of the quality of human resources in terms of the human development index which is reflected in the investment in the education and health sector, it is expected that investment in this sector will be effect on improving the quality of human resources and reducing poverty. Health and education development must be viewed as an investment to improve the quality of human resources, which is measured by the human development index (HDI). In measuring the human development index (HDI), health and education are one of the main components besides income. Health and education are also investments to support economic development and have an important role in poverty reduction efforts. The development of North Sumatera government expenditure can be seen in Figure 2 below.

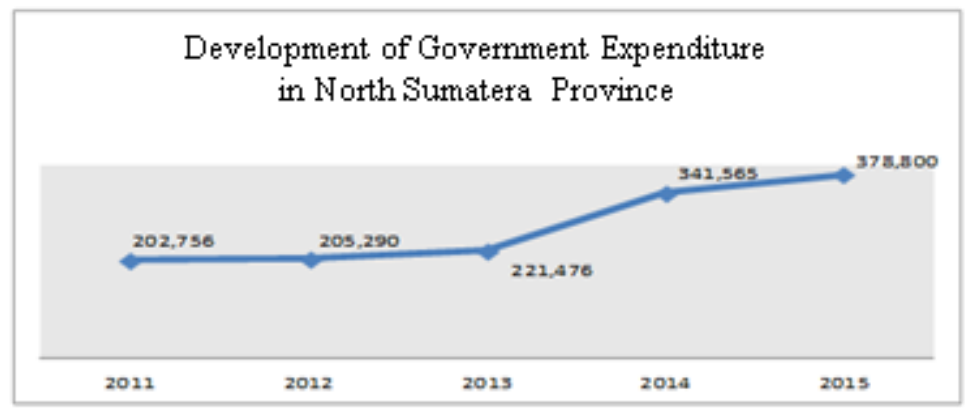

Figure 2: Development of Government Expenditure in North Sumatera Province 2011-2015

Source: BPS Indonesia (processed data) 
Based on the Figure above, it can also be seen that the proportion of government spending for regional apparatus expenditures and public service expenditures. The North Sumatera government still focuses its spending on the interests of the apparatus, even though according to the policy its spending is for the interests of the apparatus, whereas according to performance-based budget policies it should be a portion of public and apparatus and apparatus balanced. This happens as explained above, additionally because there is still a waste made by the North Sumatera government for official expenditure on official travel costs which are still relatively large, inefficient capital expenditures, excessive number of employees, and others. North Sumatera during the period 2011-2015 tended to increase. North Sumatera government spending experienced negative growth from the previous years, namely in 1998 and 2000. This is indicated because Indonesia experienced an economic crisis in 1998. The development of public service spending tends not to change much. In contrast to the expenditure of regional officials this has increased greatly high in 2012 of 121 percent from the previous year.

Seeing the above phenomena, human development is very important for strategy of national development policy. Because the quality of people in a region has a big role in determining the success of managing the development of the region. HDI really needs to be evaluated in the context of developing an area, because HDI can make a positive contribution to the welfare of the community. In addition, human development is one of the important outputs in a development planning process because HDI is a sequence of human development quality scales that measure the success of development. The ultimate goal of development is the welfare of the people. Humans are not only the object of development but are expected to become the subject, so that they can make a useful contribution to the progress of an area which at boost macro level becomes in progressing a country. The success of development is measured by several parameters, and the most popular today is the Human Development Index (HDI). This measuring tool was officially stated by Mahbub ul Haq in his book entitled Reflections on Human Development (1995), and reached to same agreement internationally through the United Nation Development Program (UNDP).

The magnitude of the index number, as necessary to simultaneously examine several factors that are thought to influence the rise and fall of HDI. HDI was developed by Amartya Sen in his book Development as Freedom (Sen, 1999). The freedom that Sen means that people can feel prosperous as a result of the development that has been achieved. This index puts forward more sensitive and detailed matters so that it is considered more effective and useful than just the per capita income that has been used so far. The four main elements in human development, are productivity, equity, sustainability, and empowerment (UNDP, 1996). UNDP measures welfare by compiling a composite index based on three indicators, namely: life expectancy at birth, adult literacy rate, mean years of schooling, and purchasing power parity. The life expectancy indicator measures health, the adult literacy rate and the average length of schooling measure education and the purchasing power measures the standard of living (UNDP, 1990). 
The following of figure 3 is the development of the human development index for the period 2011-2015:

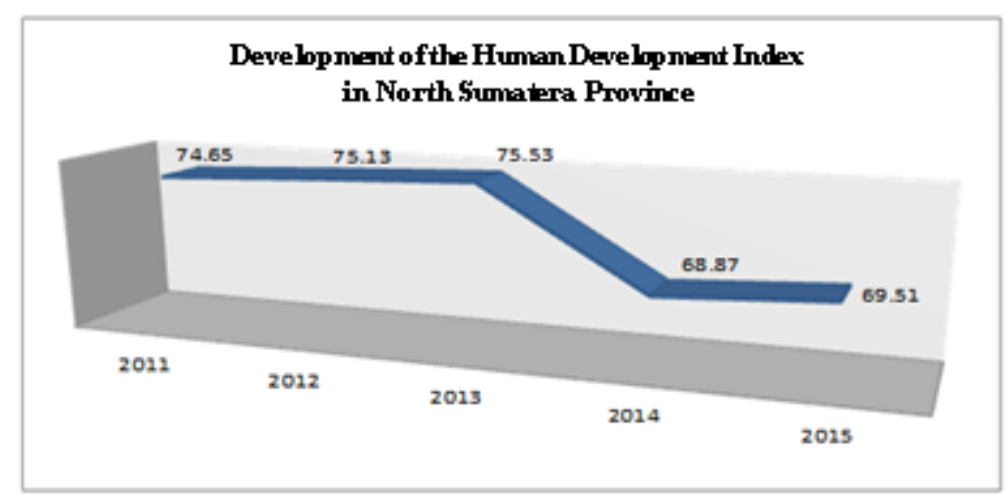

Figure 3: Development of the Human Development Index in North Sumatera Province 2011-2015

Source: BPS Indonesia (processed data)

In 2012 to 2015, the human development index has increased quite significantly. The 2013 North Sumatera Human Development Index (HDI) was 75.53\%, which places it in the 8th national rank and yet below the Riau Islands (Kepri) but positioned above Aceh Province. However, in 2015 it was ranked 10th based on the statistic calculation of the new HDI. This brought affair for the Province of North Sumatera, and so more efforts highly required to create ongoing sustain basis for the increasing the Human Development Index (HDI).

\section{RESEARCH METHOD}

This research was conducted to examine how the number of poor people, the open unemployment rate, and government education funds and health funding affect the development of the human development index (HDI) in North Sumatera. The study used panel data in the 2011-2015 periods.

The type of research data used in this study is secondary data obtained from the BPS Economic Statistics and several publications that support and relate to this study. The spatial coverage of the study is all districts / cities in North Sumatera Province, are 33 districts / cities, with a 5-year data series from 2011-2015 with a total of 165 panel data which is a combination of spatial data and time series which are quantitative data, named numerical data.

Data processing was carried out by descriptive analysis and quantitative analysis. Descriptive analysis using secondary data was staged to analyze the characteristics of the observed variables from continuing year to visualize and describe the conditions of the variables associated with the independent variables, while quantitative analysis was used by the econometric model testing method. Processing data in this study is done by Microsoft Excel 2007 and then processed by E-Views 9.0 


\section{RESULT AND DISCUSSION}

\section{Development of Human Development Index in District/city of North Sumatera}

Development is the realization of aspirations and goal of a state which is meant to create structural changes through systematic and planned efforts. The placement of HDI as one of the basic measures and benchmarks in determining the targets and objectives of regional development is determined after various methodological and empirical studies have been carried out and trials of the use of IPM in regional development planning. Since 1996 the level of regional human development has been quite impressive, as evidenced by reduced poverty and improved life expectancy and literacy (BPSBappenas-UNDP, 2001). However, this achievement immediately encountered challenges when the economic crisis hit Indonesia in 1997. As a result of the economic crisis, there was not a single province that did not experience a decline in HDI, so the $1999 \mathrm{HDI}$ was lower than the $1996 \mathrm{HDI}$. In 2002 the HDI again experienced improvements, but these improvements were generally has not been able to match the $\mathrm{HDI}$ level in 1996. There is only one province that is able to surpass the $1996 \mathrm{HDI}$, namely West Nusa Tenggara. To check more clarity of development of the HDI, the following table 1 is the HDI data for period 2011-2015

Table 1: Development of Human Development Index in District/city of North Sumatera 2011-2015

\begin{tabular}{|c|c|c|c|c|c|c|}
\hline \multirow{2}{*}{ No } & \multirow{2}{*}{ District/Town } & \multicolumn{5}{|c|}{ Human Development Index } \\
\hline & & 2011 & 2012 & 2013 & 2014 & 2015 \\
\hline 1 & $\mathrm{Nias}$ & 55.55 & 56.50 & 57.43 & 57.98 & 58.85 \\
\hline 2 & Mandailing Natal & 61.60 & 62.26 & 62.91 & 63.42 & 63.99 \\
\hline 3 & Tapanuli Selatan & 65.14 & 65.95 & 66.75 & 67.22 & 67.63 \\
\hline 4 & Tapanuli Tengah & 65.16 & 65.43 & 65.64 & 66.16 & 67.06 \\
\hline 5 & Tapanuli Utara & 69.24 & 69.83 & 70.50 & 70.70 & 71.32 \\
\hline 6 & Toba Samosir & 71.39 & 71.89 & 72.36 & 72.79 & 73.40 \\
\hline 7 & Labuhanbatu & 67.88 & 68.64 & 69.45 & 70.06 & 70.23 \\
\hline 8 & As ahan & 65.87 & 66.23 & 66.58 & 67.51 & 68.40 \\
\hline 9 & Simalungun & 69.03 & 69.79 & 70.28 & 70.89 & 71.24 \\
\hline 10 & $D$ a i r i & 66.62 & 66.95 & 67.15 & 67.91 & 69.00 \\
\hline 11 & K a r o & 71.12 & 71.40 & 71.62 & 71.84 & 72.69 \\
\hline 12 & Deli Serdang & 70.25 & 70.88 & 71.39 & 71.98 & 72.79 \\
\hline 13 & Langkat & 65.77 & 66.18 & 67.17 & 68.00 & 68.53 \\
\hline 14 & Nias Selatan & 55.50 & 55.97 & 56.78 & 57.78 & 58.74 \\
\hline 15 & Humbang Hasundutan & 64.06 & 64.54 & 64.92 & 65.59 & 66.03 \\
\hline 16 & Pakpak Bharat & 63.11 & 63.88 & 64.73 & 65.06 & 65.53 \\
\hline 17 & Samosir & 65.81 & 66.31 & 66.80 & 67.80 & 68.43 \\
\hline 18 & Serdang Bedagai & 65.28 & 66.14 & 67.11 & 67.78 & 68.01 \\
\hline 19 & Batu Bara & 63.95 & 64.45 & 65.06 & 65.50 & 66.02 \\
\hline 20 & Padang Lawas Utara & 65.22 & 65.65 & 66.13 & 66.50 & 67.35 \\
\hline 21 & Padang Lawas & 63.28 & 64.05 & 64.62 & 65.50 & 65.99 \\
\hline 22 & Labuhanbatu Selatan & 65.77 & 67.06 & 67.78 & 68.59 & 69.67 \\
\hline 23 & Labuhanbatu Utara & 67.37 & 67.84 & 68.28 & 69.15 & 69.69 \\
\hline 24 & Nias Utara & 57.53 & 57.87 & 58.29 & 59.18 & 59.88 \\
\hline
\end{tabular}




\begin{tabular}{lllllll}
25 & Nias Barat & 55.43 & 56.20 & 56.58 & 57.54 & 58.25 \\
26 & S ib olg a & 69.17 & 69.71 & 70.45 & 71.01 & 71.64 \\
27 & Tanjungbalai & 64.13 & 64.89 & 65.40 & 66.05 & 66.74 \\
28 & Pematangsiantar & 73.61 & 74.51 & 75.05 & 75.83 & 76.34 \\
29 & Tebing Tinggi & 70.84 & 71.34 & 71.85 & 72.13 & 72.81 \\
30 & M e da n & 77.54 & 77.78 & 78.00 & 78.26 & 78.87 \\
31 & B in ja i & 70.85 & 71.54 & 72.02 & 72.55 & 73.81 \\
32 & Padangsidimpuan & 71.08 & 71.38 & 71.68 & 71.88 & 72.80 \\
33 & Gunungsitoli & 63.71 & 64.34 & 65.25 & 65.91 & 66.41 \\
\hline
\end{tabular}

Source: Central Bureau of Statistics, (processed)

Based on the development, the value of the human development index (HDI) increased from 72.62 in 2011 to 74.42 in 2015. This increase occurred due to the significant increase in the human development index (HDI) in North Sumatera Province. In table 1 above, it can be stated that from the total human development index (HDI) in the province of North Sumatera, Medan Regency / City gives the greatest value compared to other districts / cities in North Sumatera Province. In the last five years, namely in 2011 and 2015, the average human development index (HDI) of Medan Regency / City was 77.90. The magnitude of the development index (IPM) of Medan Regency / City is of course directly proportional to the high level of income in North Sumatera Province. When compared with other districts / cities. Furthermore, in the second position, namely Pematang Siantar with 77.81 .

\section{Statistic of Poor Population in Districts / Cities in North Sumatera}

Poverty is a problem that continues to be the agenda and target of development policies formulated by the government. However, history records those governments have often failed and even made matters worse. For example, the government during the New Order era prioritized economic growth over the problem of income distribution (equitable distribution of economic results). At that time, the government controlled the "trickle down effect" as a strategy to achieve equity, but this strategy was not effective. The following table shows the number of poor people (JPM) during 2011-2015.

Table 2: Development of Poor Population in North Sumatera Province 2011-2015

\begin{tabular}{lllllll}
\hline \multirow{2}{*}{ No } & \multicolumn{1}{c}{ District/City } & \multicolumn{5}{c}{ Poor Population } \\
\cline { 3 - 7 } & & $\mathbf{2 0 1 1}$ & $\mathbf{2 0 1 2}$ & $\mathbf{2 0 1 3}$ & $\mathbf{2 0 1 4}$ & $\mathbf{2 0 1 5}$ \\
\hline \hline 1 & N i a s & 19.11 & 18.67 & 17.28 & 16.39 & 18.05 \\
2 & Mandailing Natal & 11.98 & 11.58 & 9.62 & 9.28 & 11.13 \\
3 & Tapanuli Selatan & 11.40 & 11.10 & 11.33 & 10.74 & 11.37 \\
4 & Tapanuli Tengah & 15.96 & 15.03 & 15.41 & 14.47 & 15.00 \\
5 & Tapanuli Utara & 11.89 & 11.55 & 11.68 & 11.06 & 11.41 \\
6 & Toba Samosir & 9.67 & 9.43 & 9.54 & 9.23 & 10.21 \\
7 & Labuhanbatu & 10.15 & 9.61 & 8.53 & 8.20 & 8.99 \\
8 & A s a h a n & 10.85 & 10.52 & 11.60 & 10.98 & 12.09 \\
9 & Simalungun & 10.21 & 9.97 & 10.45 & 10.20 & 10.96 \\
10 & D a i r i & 9.48 & 9.28 & 8.68 & 8.40 & 9.09 \\
11 & K a r o & 10.49 & 9.93 & 9.79 & 9.20 & 9.68 \\
12 & Deli Serdang & 5.10 & 4.78 & 4.71 & 4.56 & 4.74 \\
13 & L a n g k a t & 10.31 & 10.02 & 10.44 & 9.99 & 11.30 \\
14 & Nias Selatan & 19.71 & 19.05 & 18.83 & 17.81 & 19.05
\end{tabular}

QE Journal | Vol.08 - No.01 - 89 


\begin{tabular}{lllllll}
15 & Humbang Hasundutan & 10.09 & 9.73 & 10.00 & 9.44 & 9.85 \\
16 & Pakpak Bharat & 13.16 & 12.40 & 11.28 & 10.55 & 11.26 \\
17 & Samosir & 15.67 & 15.17 & 14.01 & 13.20 & 14.11 \\
18 & Serdang Bedagai & 10.07 & 9.89 & 9.35 & 8.98 & 9.59 \\
19 & Batu Bara & 11.67 & 11.24 & 11.92 & 11.25 & 12.61 \\
20 & Padang Lawas Utara & 10.64 & 9.98 & 10.28 & 9.60 & 10.97 \\
21 & Padang Lawas & 10.56 & 9.80 & 8.59 & 8.03 & 8.73 \\
22 & Labuhanbatu Selatan & 14.86 & 13.96 & 12.36 & 11.54 & 11.65 \\
23 & Labuhanbatu Utara & 11.77 & 11.34 & 11.34 & 10.71 & 11.31 \\
24 & Nias Utara & 30.44 & 29.50 & 30.94 & 29.28 & 32.62 \\
25 & Nias Barat & 29.32 & 28.57 & 29.65 & 28.10 & 29.96 \\
26 & S i b o I g a & 13.18 & 13.00 & 12.90 & 12.26 & 13.48 \\
27 & Tanjungbalai & 15.52 & 14.86 & 14.85 & 14.02 & 15.08 \\
28 & Pematangsiantar & 11.15 & 10.79 & 10.93 & 10.35 & 10.47 \\
29 & Tebing Tinggi & 12.44 & 11.93 & 11.74 & 11.08 & 12.03 \\
30 & M e d a n & 9.63 & 9.33 & 9.64 & 9.12 & 9.41 \\
31 & B in j a i & 7.00 & 6.72 & 6.75 & 6.38 & 7.03 \\
32 & Padangsidimpuan & 10.08 & 9.60 & 9.04 & 8.52 & 8.77 \\
33 & Gunungsitoli & 32.12 & 30.85 & 30.94 & 27.63 & 25.42 \\
\hline
\end{tabular}

Source: Central Bureau of Statistics, (processed)

The development of the number of poor people in North Sumatera from 2011-2015 experienced fluctuations due to turbulent regional economic conditions in North Sumatera. Among them is the global crisis that occurred in 2006, practically increased drastically, initially in 2004 it was only 14.93 percent while in 2005 it was 14.68 percent, but in 2006 it increased. The global crisis that occurred had a significant impact on JPM in North Sumatera, however in 2008 the number of JPM in North Sumatera decreased drastically, even exceeding the pre-crisis period. Based on table 2 above, it can be explained that Regencies / Cities which have a low percentage of poverty in North Sumatera Province, Deli Serdang, Binjai and Labuhan Batu, when viewed and connected with the human development index in the Regency / City have a more stable human development index value.

\section{Development of Government Expenditure on Health and Education in the District / City of North Sumatera Province}

Based on the Minister of Finance Regulation Number: 171.1 / PMK.07 / 2011, Number: 175 / PMK.07 / 2012, Number: 216 / PMK.07 / 2013, Number: 09 / PMK.07 / 2014, Number: 180 / PMK. 07/2015 regarding the determination of the Special Fund Allocation for the 2011-2015 Budget for North Sumatera, the development of Education and Health Fund Expenditures for the Province of North Sumatera for a period of 5 years, from 2011 to 2015, has fluctuated for each Regency / City in North Sumatera Province.

Table 3: Development of Education Fund Expenditures for Regency / Municipality in North Sumatera Province, 2011-2015

\begin{tabular}{llrrrrr}
\hline \multirow{2}{*}{ No } & \multirow{2}{*}{ District/Town } & \multicolumn{5}{c}{ Education Fund Expenditures } \\
\cline { 3 - 7 } & & $\mathbf{2 0 1 1}$ & $\mathbf{2 0 1 2}$ & $\mathbf{2 0 1 3}$ & $\mathbf{2 0 1 4}$ & $\mathbf{2 0 1 5}$ \\
\hline \hline 1 & N i a s & 32,960 & 28,148 & 19,089 & 23,101 & 15,602 \\
2 & Mandailing Natal & 21,951 & 31,941 & 22,459 & 16,576 & 15,093
\end{tabular}




\begin{tabular}{|c|c|c|c|c|c|c|}
\hline 3 & Tapanuli Selatan & 32,171 & 19,751 & 20,120 & 18,322 & 18,391 \\
\hline 4 & Tapanuli Tengah & 25,330 & 29,855 & 23,332 & 19,671 & 21,547 \\
\hline 5 & Tapanuli Utara & 33,676 & 26,956 & 27,727 & 18,382 & 24,356 \\
\hline 6 & Toba Samosir & 21,600 & 24,358 & 15,310 & 18,902 & 14,178 \\
\hline 7 & Labuhanbatu & 18,379 & 23,341 & 19,976 & 55,608 & 25,081 \\
\hline 8 & Asahan & 41,398 & 23,271 & 25,172 & 36,218 & 37,183 \\
\hline 9 & Simalungun & 46,077 & 37,374 & 37,434 & 58,894 & 43,732 \\
\hline 10 & D a i r i & 21,966 & 20,139 & 18,976 & 12,442 & 21,576 \\
\hline 11 & K a r o & 22,057 & 22,219 & 14,836 & 12,404 & 16,836 \\
\hline 12 & Deli Serdang & 56,303 & 49,988 & 35,893 & 28,815 & 43,815 \\
\hline 13 & Langkat & 28,757 & 34,315 & 31,135 & 22,739 & 36,181 \\
\hline 14 & Nias Selatan & 15,854 & 42,053 & 32,670 & 37,586 & 32,445 \\
\hline 15 & Humbang Hasundutan & 23,911 & 12,245 & 14,228 & 9,898 & 18,302 \\
\hline 16 & Pakpak Bharat & 14,024 & 7,637 & 9,229 & 6,064 & 8,481 \\
\hline 17 & Samosir & 26,897 & 20,941 & 14,534 & 13,432 & 14,251 \\
\hline 18 & Serdang Bedagai & 35,447 & 32,412 & 32,662 & 33,127 & 32,603 \\
\hline \multirow{2}{*}{ No } & \multirow{2}{*}{ District/Town } & \multicolumn{5}{|c|}{ Educational Fund Expenditures } \\
\hline & & 2011 & 2012 & 2013 & 2014 & 2015 \\
\hline 19 & Batu Bara & 13,059 & 20,683 & 16,021 & 26,756 & 20,855 \\
\hline 20 & Padang Lawas Utara & 22,827 & 16,545 & 16,218 & 20,222 & 14,143 \\
\hline 21 & Padang Lawas & 23,355 & 21,677 & 12,419 & 13,120 & 11,439 \\
\hline 22 & Labuhanbatu Selatan & 26,647 & 11,842 & 12,217 & 17,420 & 23,688 \\
\hline 23 & Labuhanbatu Utara & 28,240 & 13,015 & 18,030 & 13,339 & 24,936 \\
\hline 24 & Nias Utara & 22,414 & 13,821 & 20,500 & 16,204 & 19,746 \\
\hline 25 & Nias Barat & 15,218 & 11,233 & 21,926 & 34,204 & 20,718 \\
\hline 26 & Sibolga & 14,323 & 8,684 & 7,410 & 7,502 & 12,040 \\
\hline 27 & Tanjungbalai & 12,118 & 9,440 & 6,108 & 4,696 & 8,454 \\
\hline 28 & Pematangsiantar & 10,513 & 12,960 & 24,617 & 10.35 & 10.47 \\
\hline 29 & Tebing Tinggi & 11,421 & 8,040 & 7,293 & 5,041 & 14,851 \\
\hline 30 & Medan & 20,993 & 35,121 & 44,857 & 36,799 & 49,038 \\
\hline 31 & Binjai & 10,603 & 15,459 & 9,417 & 8,813 & 15,716 \\
\hline 32 & Padangsidimpuan & 14,110 & 9,333 & 9,253 & 7,324 & 14,086 \\
\hline 33 & Gunungsitoli & 21,964 & 11,385 & 23,386 & 27,645 & 15,215 \\
\hline
\end{tabular}

Source: Central Bureau of Statistics, (processed)

Table 4: Development of District / Municipal Health Fund Expenditures in North Sumatera Province, 2011-2015

\begin{tabular}{lllcccc}
\hline \multirow{2}{*}{ No } & \multirow{2}{*}{ District/Town } & \multicolumn{5}{c}{ Educational Fund Expenditures } \\
\cline { 3 - 6 } & & $\mathbf{2 0 1 1}$ & $\mathbf{2 0 1 2}$ & $\mathbf{2 0 1 3}$ & $\mathbf{2 0 1 4}$ & $\mathbf{2 0 1 5}$ \\
\hline \hline 1 & N i a s & 1,393 & 4,173 & 7,001 & 4,122 & 5,409 \\
2 & Mandailing Natal & 6,799 & 7,141 & 3,164 & 6,980 & 6,689 \\
3 & Tapanuli Selatan & 4,082 & 4,347 & 4,512 & 6,610 & 5,607 \\
4 & Tapanuli Tengah & 6,723 & 6,160 & 5,912 & 6,655 & 7,051 \\
5 & Tapanuli Utara & 7,102 & 5,533 & 3,948 & 5,460 & 5,413 \\
6 & Toba Samosir & 6,338 & 3,283 & 2,881 & 5,231 & 6,385
\end{tabular}

QE Journal | Vol.08 - No.01 - 91 


\begin{tabular}{lllllll}
7 & Labuhanbatu & 1,091 & 3,728 & 4,186 & 3,095 & 5,403 \\
8 & A s a h a n & 9,045 & 5,723 & 5,712 & 4,583 & 6,923 \\
9 & Simalungun & 9,824 & 5,690 & 3,798 & 8,190 & 6,085 \\
10 & D a i r i & 8,231 & 6,259 & 2,708 & 5,310 & 5,237 \\
11 & K a r o & 7,633 & 3,871 & 2,434 & 5,352 & 4,867 \\
12 & Deli Serdang & 9,058 & 10,326 & 7,636 & 11,772 & 3,172 \\
13 & L a n g k a t & 9,697 & 6,549 & 4,427 & 9,891 & 6,447 \\
14 & Nias Selatan & 8,026 & 5,025 & 5,039 & 6,396 & 11,595 \\
15 & Humbang Hasundutan & 5,890 & 4,288 & 2,666 & 4,600 & 4,950 \\
16 & Pakpak Bharat & 5,760 & 5,250 & 1,986 & 4,652 & 5,486 \\
17 & Samosir & 7,031 & 6,132 & 2,706 & 2,724 & 4,817 \\
18 & Serdang Bedagai & 8,296 & 6,660 & 5,563 & 6,410 & 7,420 \\
19 & Batu Bara & 8,488 & 4,920 & 4,153 & 4,317 & 4,535 \\
20 & Padang Lawas Utara & 7,775 & 4,036 & 5,654 & 4,684 & 3,203 \\
21 & Padang Lawas & 1,797 & 5,006 & 6,253 & 7,318 & 3,859 \\
22 & Labuhanbatu Selatan & 2,664 & 3,767 & 4,318 & 4,280 & 7,238 \\
23 & Labuhanbatu Utara & 2,824 & 2,142 & 6,331 & 7,352 & 2,989 \\
\hline
\end{tabular}

Source: Central Bureau of Statistics, (compiled)

Based on table 3 above, the lowest education level seen from the population aged 10 years and over who passed the last high school education and above was in West Nias Regency, which was 11.04 percent in 2015 and the highest was in Medan, which was 53 , 09 percent in 2015. This is because the city of Medan is the capital of North Sumatera Province where there are many public high schools and private high schools and there are state universities and private universities that are equipped with the facilities and infrastructure needed for the continuation of the educational process. So that people's access to education is easier when compared to other districts / cities in North Sumatera Province. Therefore, Medan City is also one of the educational target cities for students from all districts / cities in North Sumatera Province to continue their education to higher levels, namely Senior High Schools and Universities. As for the increase in changes in the level of education in districts / cities in North Sumatera Province, the highest was in South Nias Regency in 2015, amounting to 38.62 percent, while the lowest decrease in education level was in West Nias Regency, namely 50.81 percent.

\section{Development of Open Unemployment Rate in Regencies / Cities in North Sumatera}

The burden of each economic sector is getting higher because an increase in population will increase the demand for labor. However, limitations in the absorption of labor in the economic sector are not matched by growth in employment, so the unemployment rate will still be high. Open unemployment includes people who are looking for work, who are preparing for the business world, people who feel they might get a job, and who already have a job. venture but haven't started working yet.

Table 5: Development of Open Unemployment Rate in Regencies / Cities in North Sumatera Province, 2011-2015

\begin{tabular}{|c|c|c|c|c|c|c|}
\hline \multirow{2}{*}{ No } & \multirow{2}{*}{ District /City } & \multicolumn{5}{|c|}{ Open Unemployment Rate } \\
\hline & & 2011 & 2012 & 2013 & 2014 & 2015 \\
\hline 1 & $\mathrm{Nias}$ & 4.69 & 0.15 & 0.87 & 0.44 & 0.92 \\
\hline
\end{tabular}




\begin{tabular}{|c|c|c|c|c|c|c|}
\hline 2 & Mandailing Natal & 4.52 & 6.42 & 8.02 & 6.55 & 5.78 \\
\hline 3 & Tapanuli Selatan & 4.18 & 2.42 & 4.46 & 7.6 & 7.6 \\
\hline 4 & Tapanuli Tengah & 5.22 & 5.26 & 8.53 & 4.9 & 4.98 \\
\hline 5 & Tapanuli Utara & 3.85 & 2.27 & 2.34 & 0.59 & 2.56 \\
\hline 6 & Toba Samosir & 2.35 & 1.98 & 1.69 & 0.73 & 3.47 \\
\hline 7 & Labuhanbatu & 5.88 & 7.8 & 8.93 & 7.72 & 11.4 \\
\hline 8 & Asahan & 6.14 & 7.32 & 5.22 & 1.84 & 5.82 \\
\hline 9 & Simalungun & 4.62 & 5.41 & 5.56 & 7.48 & 5.75 \\
\hline 10 & $\mathrm{D} a \mathrm{i} \mathrm{r}$ & 2.6 & 1.43 & 1.9 & 1.5 & 1.26 \\
\hline 11 & $\mathrm{~K}$ a r o & 4.46 & 2 & 2.08 & 1.02 & 2.23 \\
\hline 12 & Deli Serdang & 7.69 & 6.85 & 7.54 & 7 & 6.38 \\
\hline 13 & Langkat & 5.78 & 5.98 & 7.1 & 6.6 & 8.02 \\
\hline 14 & Nias Selatan & 5.23 & 0.48 & 2.79 & 0.49 & 0.4 \\
\hline 15 & Humbang Hasundutan & 3.56 & 0.35 & 0.3 & 0.36 & 1.22 \\
\hline 16 & Pakpak Bharat & 3.92 & 1.13 & 3.57 & 2.64 & 2.88 \\
\hline 17 & Samosir & 2.26 & 1.31 & 1.12 & 1.05 & 1.28 \\
\hline 18 & Serdang Bedagai & 4.89 & 5.68 & 6.13 & 7.14 & 7.18 \\
\hline 19 & Batu Bara & 4.97 & 6.77 & 6.98 & 7.42 & 6.32 \\
\hline 20 & Padang Lawas Utara & 4.61 & 6.59 & 3.91 & 10.9 & 5.01 \\
\hline 21 & Padang Lawas & 4.95 & 7.47 & 4.85 & 5.66 & 5.95 \\
\hline 22 & Labuhanbatu Selatan & 3.92 & 8.55 & 8.86 & 4.83 & 4.15 \\
\hline 23 & Labuhanbatu Utara & 4.93 & 7.23 & 7.61 & 10.9 & 8.75 \\
\hline 24 & Nias Utara & 4.75 & 3.52 & 3.39 & 2.71 & 4.02 \\
\hline 25 & Nias Barat & 3.83 & 1.18 & 0.91 & 1 & 2.96 \\
\hline 26 & Sibolga & 9.82 & 19.2 & 10.1 & 12.4 & 10.3 \\
\hline 27 & Tanjungbalai & 10.9 & 14.8 & 8.98 & 8.05 & 10.1 \\
\hline 28 & Pematangsiantar & 9.5 & 6.14 & 6.61 & 9.26 & 9.47 \\
\hline 29 & Tebing Tinggi & 8.36 & 11.3 & 7.36 & 7.23 & 10.5 \\
\hline 30 & Medan & 9.97 & 9.03 & 10 & 9.48 & 11 \\
\hline 31 & Binjai & 8.73 & 9.8 & 6.83 & 7.6 & 10 \\
\hline 32 & Padangsidimpuan & 8.81 & 9.1 & 6.8 & 6.29 & 6.96 \\
\hline 33 & Gunungsitoli & 6.09 & 7.93 & 8.36 & 8.06 & 10 \\
\hline
\end{tabular}

Source: Central Bureau of Statistics, (processed)

Table 5 shows that in 2012 the open unemployment rate in North Sumatera was 6.20 percent. This figure is indeed smaller than that in 2011 and 2010 which amounted to 6.37 percent and 7.43 percent, respectively, but was still above the national TPT average for the same two years, namely 2012 and 2013 which was 5.92\%. The downward trend in the open unemployment rate is certainly a positive signal for welfare in North Sumatera. Until 2013, the unemployment rate in North Sumatera continued to decline.

\section{Specification Test of Panel Data Regression Model}

To determine the approach or method in estimating panel data regression, the procedures that must be done in estimating panel data regression are:

1. CHOW test to choose between Pooled Least Square (PLS) and Fixed Effect Model (FEM) approaches. 
2. Hussman test to choose between Fixed Effect Model and Random Effect Model (REM) approaches.

Table 6: Results of the Chow Test Statistics (Likelihood Test)

\begin{tabular}{llll}
\hline Effect Test & Statistic & d.f & Prob \\
\hline Cross-section F & 869.401260 & $(31,120)$ & 0.0000 \\
Cross-section Chi-square & 866.998848 & 31 & 0.0000 \\
\hline
\end{tabular}

Source: EViews 9.0 Panel Data Output Results

Based on table 6 above, it is found that the probability value ( $p$-value) of cross section $F$ and Chi Square is 0.0000 <significant error $\alpha=0.05$, so that it is rejected, so between the pooled least square model and the fixed effect model, according to Chow results above are used is the fixed effect model.

\section{Panel Data Regression Estimation Results with the Fixed Effect Model Method}

The estimation model in this study uses Eviews 9.0 software with the fixed effect model method to see the percentage of poverty, government spending in the health sector, government spending in education and the open unemployment rate (PT) have an influence on the development index. Human (HDI) in 33 Regencies / Cities in North Sumatera Province. Based on the panel data regression estimation output using the fixed effect model method above, the estimation results can be seen in table 7 .

Table 7: Panel Data Regression Estimation Results with Fixed Effect Model

\begin{tabular}{|c|c|c|c|c|}
\hline Variable & Coefficient & Std. Error & t-Statistic & Prob. \\
\hline $\mathrm{C}$ & 68.45641 & 0.531666 & 128.7584 & 0.0000 \\
\hline JPM? & -0.119609 & 0.041983 & -2.848994 & 0.0052 \\
\hline PD? & 4.97E-06 & $3.54 \mathrm{E}-06$ & 1.403970 & 0.1629 \\
\hline PK? & $2.58 \mathrm{E}-05$ & $1.15 \mathrm{E}-05$ & 2.250923 & 0.0262 \\
\hline PT? & 0.003627 & 0.013023 & 0.278486 & 0.7811 \\
\hline R-squared & 0.998199 & \multicolumn{2}{|c|}{ Mean dependent var } & 67.24855 \\
\hline Adjusted R-squared & 0.997614 & \multicolumn{2}{|c|}{ S.D. dependent var } & 5.041447 \\
\hline S.E. of regression & 0.246270 & \multicolumn{2}{|l|}{ F-statistic } & 1649.562 \\
\hline Sum squared resid & 7.277855 & \multicolumn{2}{|c|}{ Prob(F-statistic) } & 0.000000 \\
\hline Log likelihood & 0.0000 & \multicolumn{2}{|c|}{ Durbin-Watson stat } & 1.104922 \\
\hline
\end{tabular}

Source: Eviews 9.0 Panel Data Output Results

The interpretation of the final model selection used in this study is in accordance with the results of the data output and in accordance with the tests that have been carried out in the study using the fixed effect model. Differences in individual characteristics and time are accommodated in the intercept, so that the human development index (HDI) of each Regency / City in North Sumatera Province is different as well as the different constants and when interpreted for each Regency / City in North Sumatera Province, the results will of course also be different. But in general the similarities of this research are as follows:

$$
I P M=68.45641-0.119609 \mathrm{JPM}+4.97 E 06 \mathrm{PD}+2.58 E 05 \mathrm{PK}+0.003627 \mathrm{PT}+\text { et }
$$




\section{Simultaneous Test Results (F-Statistics)}

The Counting value is 1649,562 and the probability value is 0.000000 . This means that together (simultaneously) the independent variables, namely poverty, government spending from the health aspect, the education aspect and the district / municipality open unemployment have an effect on the dependent variable of the human development index in North Sumatera Province. The estimation results have met the suitability test of the model for simultaneous testing, so that the estimation results can be used for analysis.

\section{Result of the coefficient of determination $\left(R^{2}\right)$}

$R 2$ is located between 0 and $R^{2}$ is equal to 1 , meaning that the independent variables explain 100 percent of the variation in the dependent variable. Conversely, $R 2$ is equal to 0 , meaning that the independent variables in the model do not explain the slightest variation in the dependent variable. The model is said to be better if $R 2$ is closer to 1 (Gujarati, 2003). The model estimate yields $R^{2}$ of 0.998199 . This means that the existence of poverty-free variables, health aspects of government expenditure, education aspects and open unemployment at districts / cities is able to explain the dependent variable on the human development index of 99.81 percent; the remaining 0.19 percent is explained by other variables outside the model.

\section{Partial Test Result (T-test)}

The $t$-test (partial) in this study was conducted to determine whether there was a significant influence between poverty (JPM), health aspects of government spending (KES), education aspects of government spending (PE), and open unemployment (PT) had an effect on the human development index (IPM). Through the $t$ test with each level of significance, the estimation results of the t-statistic value and probability of each variable can be seen in table 8 below:

Table 8: Partial Test Hypothesis Test Results

\begin{tabular}{llll}
\hline Variable & Coefficient & t-Statistic & Prob. \\
\hline \hline JPM? & -0.119609 & -2.848994 & $0.0052^{*}$ \\
PD? & $4.97 \mathrm{E}-06$ & 1.403970 & 0.1629 \\
PK? & $2.58 \mathrm{E}-05$ & 2.250923 & $0.0262^{*}$ \\
PT? & 0.003627 & 0.278486 & 0.7811 \\
\hline
\end{tabular}

Source: Eviews 9.0 (processed)

Table 8 above, proves that the $t$-count value of the poverty variable (JPM) with a $t$-stat value $=-2.848994$, prob. $=0.0052$, meaning that statistically the poverty variable (JPM) has a significant effect on the human development index (HDI). In North Sumatera Province. The variable of government expenditure in the education aspect (PD) with a tstat value $=1.403970$ and prob. $=0.1629$, meaning that it can be interpreted that statistically the health aspect government expenditure variable (PD) has no significant effect on the human development index (HDI) in North Sumatera Province. The health aspect government expenditure variable (PK) with a t-stat value $=2.250923$ and prob. $=$ 0.0262 , meaning that it can be interpreted that statistically the health aspect QE Journal |Vol.08 - No.01 - 95 
government expenditure variable (PK) has a significant effect on the human development index (HDI) in North Sumatera Province. The open unemployment variable $(\mathrm{PT})$ with a t-stat value $=0.278486$ and prob. $=0.7811$, meaning that it can be interpreted that statistically the open unemployment variable (PT) has no significant effect on the human development index (HDI) in North Sumatera Province.

\section{CONCLUSIONS AND RECOMMENDATIONS}

\section{Conclusion}

Based on the estimation results of the determinants of the human development index in North Sumatera with a multiple linear regression estimation model, panel data on the influence of independent variables such as the number of poor people (JPM), the open unemployment rate (PT) and government spending in terms of health aspects (PK) and education (PD), in North Sumatera in 2011-2015, it can be concluded as follows:

1. The number of poor people has a negative and significant effect on the human development index.

2. Government Expenditures on education aspects has a positive and insignificant effect on the human development index.

3. Government Expenditure on health system has a positive and significant effect on the human development index.

4. The open unemployment rate has a positive and insignificant effect on the human development index.

\section{Suggestion}

1. Trend of fiscal decentralization, regions are required to carry out their functions effectively and efficiently, especially in programs / activities aimed at increasing the Human Development Index (HDI). Therefore, local governments are expected to be able to increase their fiscal capacity and increase allocations for programs and activities related to increasing HDI.

2. It is expected that local governments will not only pursue economic improvement, but require strong political will in order to realize a high HDI, by increasing human resources so that they can increase the welfare of the community. The effort to create regional output is expected to be able to boost labor and reduce unemployment. By then a decrease in the number of unemployed and an increase in the allocation of government Expenditure can increase the HDI.

3. The government is required to pay attention to issues related to government expenditure on health and education. In the health sector, public facilities can be built, especially in the health sector, such as the construction of hospitals and medical centers, as well as improving the quality of nutrition for facilities for the poor individuals and Clinic center, mainly in the rural and underdeveloped areas.

4. Budget expenditure invests in education sector must be sufficient because it plays major and crucial role to improve the human development index. 


\section{REFERENCES}

Afza, T. dan H.H. Mirza. 2011. "Institutional Shareholdings and Corporate Dividend Policy in Pakistan". African Journal of Business Management, Vol. 5, No. 22, pp 89418951

Arsyad, Lincolin. 2010. Ekonomi Pembangunan, Yogyakarta: UPP STIE YKPN.

Astri, Meylina dkk.(2013). "Pengaruh Pengeluaran Pemerintah Daerah pada Sektor Pendidikan and Kesehatan Terhadap Indeks Pembangunan Manusia di Indonesia".Jurnal Pendidikan Ekonomi dan Bisnis. Vol.1 No. 1, hal:77-102.

Agustin, N. and H. Sasana.2012. Analisis Konsumsi Rumah Tangga Petani Padi dan Palawija di Kabupaten Demak. Diponogoro Journal Of Economics. Volume 1, Nomor 1, Tahun 2012, Halaman 1-11

Baeti, Nur. 2013. Pengaruh Pengangguran, pertumbuhan ekonomi, Dan Pengeluaran Pemerintah Terhadap Pembangunan Manusia Kabupaten/Kota Di Provinsi Jawa Tengah Tahun 2007-201. Jurnal Ekonomi Pembangunan. Universitas Negeri Semarang.

Badan Pusat Statistik. 2009. Statistik Indonesia. Berbagai Edisi Tahun Penerbitan (19972015). Jakarta.

BPS-Statistic Indonesia, UNDP, BAPPENAS, 2004. National Human Development Report 2004. The Economics of Democracy: Financing Human Development in Indonesia.

Bakti, Pramilu Galih dan Kodoatie, Maria Johanna. 2012. “Analisis Dampak Desentralisasi Fiskal Terhadap Angka Melek Huruf Perempuan Dan Angka Partisipasi Sekolah Perempuan Di Kabupaten/Kota Provinsi Daerah Istimewa Yogyakarta". Vol. 1, No. 1

Dumairy (2006).Perekonomian Indonesia. Jakarta : Erlangga.

Guritno,BambangdanWaridin.(2005). Pengaruh Persepsi Karyawan Mengenai Perilaku Kepemimpinan, Kepuasan Kerja dan Motivasi Terhadap Kinerja. Jurnal Riset Bisnis Indonesia Vol.1 No.1, p. 63-74.

Ginting, Charisma Kuriata, Lubis, Mahalli, 2008. Pembangunan Manusia di Indonesia dan Faktor- faktor yang mempengaruhinya.

Gujarati, Damodar, 2003, Basic Econometrics, MacGraw-Hill Book Co., Fourth Edition.

Kuncoro, M., 2006. Ekonomi Pembangunan: Teori, Masalah, dan Kebijakan. Yogyakarta: UPP AMP YKPN.

Maipita, Indra. 2014. Mengukur Kemiskinan dan Distribusi Pendapatan. Yogyakarta. UPP STIM YKPN

Mangkoesoebroto, Guritno (2002). Ekonomi Publik. Yogyakarta: BPFE.

Manurung, Jonni J., Manurung, Adler H., Saragih, Ferdinand D. 2005. Ekonometrika. Cetakan Pertama. Penerbit Elex Media Computindo. Jakarta. 
Maryani, Tri, 2010. Analisis Indeks Pembangunan Manusia di Provinsi Jawa Tengah. Yogyakarta: Jurnal UPN.

Subandi, 2011. Ekonomi Pembangunan, CetakanKesatu, Alfabeta, Bandung.

Suradi.2002. Selintas: Pengembangan Masyarakat. Jurnal Ilmiah Teknologi Pengembangan Masyarakat. LPM STKSPRESS : Bandung.

Sukirno, Sadono. 2004. Makro Ekonomi Modern. PT. Raja Grafindo Perkasa, Jakarta

Seda, Frans. 2009. Era Baru Kebijakan Fiskal, Gramedia, Jakarta.

Sugiyono. 2012. Metode Penelitian Pendidikan: Pendekatan Kuantitatif, Kualitatif dan $R \& D$. Bandung: Alfabeta.

Sen, A.K. 1999. Development as Freedom. New York: Oxford University Press.

Todaro, Michael P dan Stephen C. Smith. 2006. Pembangunan Ekonomi. Edisi ke-9. Terjemahan oleh Haris Munandar dan Puji A.I. Erlangga. Jakarta (On-line)

UlHaq, Mahbub. 1998. Reflections on Human Development. Oxford. CUP.

UNDP.1990-2009. Human Development Report. UNDP

Widarjono, Agus, 2009. Ekonometrika Untuk Analisis Ekonomi dan Keuangan. Jakarta: $\mathrm{UI}$

World Bank. 2006. Era Baru Dalam Pengentasan Kemiskinan di Indonesia. 